\title{
North American population estimates of waterbirds, vultures and hawks from migration counts in Veracruz, México
}

\author{
ERNESTO RUELAS INZUNZA, LAURIE J. GOODRICH and \\ STEPHEN W. HOFFMAN
}

\begin{abstract}
Summary
Continental-scale bird population estimates are used as a decision-support tool in conservation plans. The calculation of these estimates includes the use of density values and survey data from one or multiple sources extrapolated to the geographic scale of interest. In this paper, we use migration count data from a migration monitoring project in Veracruz, Mexico, to revise existing North American population estimates of seven species of waterbirds, New World vultures, and diurnal raptors. In two species of waterbirds, we suggest that existing estimates are low and propose a mechanism to correct these figures. In the remaining five cases, we also determine present estimates are low, but use our data to provide new continental-scale values. We discuss the importance of refining population estimates using data from a diverse suite of field methods as a means to overcome the limitations of the single-survey-based estimates.
\end{abstract}

\section{Resumen}

Las estimaciones de poblaciones de aves a escala continental son utilizadas como una herramienta de toma de decisiones en planes de conservación. Su cálculo incluye el uso de valores de densidad demográfica y datos de reconocimientos de campo de una o más fuentes que son extrapolados a la escala geográfica de interés. En este artículo utilizamos conteos de migración de un proyecto de monitoreo en Veracruz, México, para ajustar las estimaciones poblacionales para Norteamérica de siete especies de aves acuáticas, zopilotes del nuevo mundo y rapaces diurnas. En dos especies de aves acuáticas, sugerimos que las estimaciones existentes son bajas y proponemos un mecanismo para corregir estas cifras. En los restantes cinco casos, determinamos que éstas también son bajas, pero usamos nuestros datos de campo para proporcionar nuevos valores da escala continental. Discutimos la importancia de refinar la estimación de poblaciones utilizando datos de varios muestreos de campo como forma de superar las limitaciones de aquellas que se basan en una sola fuente de información.

\section{Introduction}

Estimating the true, total number of birds per unit area is one of the central problems of avian population biology and addressing this question is of utmost importance, since population estimates are decision-support tools of critical value for conservation and management. Within the context of biological and ecological inquiry, this issue has been approached from small-tolarge scales, with literally dozens of techniques employed to estimate population numbers in areas that range in size roughly from $I \times 10^{2}$ to $1 \times 10^{6} \mathrm{~m}^{2}$ (e.g. Ralph and Scott 1981 , Bibby et al. 2000). 
The precision of those estimates decreases as researchers increase the geographic extent of the study (e.g. Flather and Sauer 1996). Habitat heterogeneity and its resulting variation in density of occupation, the scale of sampling, number of individuals that are undetected but present, and many other sources of error, affect their precision.

At the other end of the spectrum, large-scale estimates ranging from state to continental (roughly from $1 \times 10^{8}-1 \times 10^{10} \mathrm{~m}^{2}$ ), have received considerable attention in recent years as benchmarks to evaluate the success of conservation measures (Fitzpatrick 2002).

The European bird conservation community initiated this approach and organized a group of ornithologists to calculate country estimates for all species. These first results were published 15 years ago (Tucker et al. 1994), with a subsequent assessment published a decade later (Burfield and van Bommel 2004).

Global population estimates, such as those made for waterbirds (Delany and Scott 2006), involve the contribution of data from multiple field projects that are then summarized into a single figure. Since Delany and Scott's (2006) publication is the fourth iteration of this work, they also provide calculations of population change.

In North America, the Partners in Flight coalition (PIF) released a North American Landbird Conservation Plan (Rich et al. 2004) that contains an appendix with continental-scale population estimates for 448 species derived predominantly from Breeding Bird Survey data (BBS). The confidence of these values is scored in six categories of "accuracy rating" and seven categories of "precision." In the geographic scope of Rich et al. (2004: 6), "North American" excludes México, and we adopt this convention for the purpose of this paper.

These first North American estimates are a useful reference point of central importance. The authors of them (Rich et al. 2004, Rosenberg and Blancher 2005) have acknowledged their conservative nature and have invited the contribution of data from other sources in refining them. Most of the reviews and discussion over the conservation plan, however, have addressed programmatic aspects (e.g. Faaborg 2005, Vickery and Shriver 2005), and only Thogmartin et al. (2006) have covered the topic of the population estimates, with suggestions to improve the analyses for deriving them. Although we strongly support the idea of improving precision through enhancements in analysis methods, we also think that an approach that incorporates other empirical data can help us reach the goal of better figures.

In this paper, we present a case study of new North American population estimates for seven species of waterbirds, vultures, and diurnal raptors based on our long-term research in Veracruz, México. We recognize that our migration-count-based suggested revisions are more compelling for species whose breeding range lies entirely north of Mexico and winter range south of Veracruz. In three cases (waterbirds), we use our field data to indicate that existing figures are underestimates and suggest a mechanism to produce more appropriate calculations. In the remaining four cases (vultures and hawks), we use our migration count data to produce new estimates. In the closing section of this paper, we discuss the importance of incorporating data from multiple types of surveys to improve global and continental estimates, particularly (but not exclusively) those of the PIF.

\section{Methods}

Since 1991, we have made standardized vulture, hawk, and waterbird migration counts during (boreal) spring and autumn seasons in Veracruz, México. This region is a geographic bottleneck for migrants. It is located at the intersection of two major mountain systems, the Sierra Madre Oriental and the Central Volcanic Belt, which constrain the width of the Gulf Coastal Plain at about $19^{\circ} \mathrm{N}, c .30 \mathrm{~km}$ north of Veracruz City (Ruelas et al. 2000, 2005).

These migration counts are made annually from two fixed locations $11 \mathrm{~km}$ apart (Cardel, $19^{\circ} 22^{\prime} \mathrm{N}-96^{\circ} 22^{\prime} \mathrm{W}$, elevation $29 \mathrm{~m}$, and Chichicaxtle $19^{\circ} 21^{\prime} \mathrm{N}-96^{\circ} 28^{\prime} \mathrm{W}$, elevation $120 \mathrm{~m}$ ), along an east-to-west axis (perpendicular to the front of migration). Both sites are independent samples of the flow of birds migrating through the area, as the distance between sites does not allow 
double counts, and the combined totals from these localities are used for long-term population monitoring. Because the goal of this project is monitoring rather than an attempt to quantify the total number of migrants in transit through the region, we know we are missing a proportion of the population that migrates east and west of our field stations. Most of the waterbirds regularly recorded from our migration sites rarely fly over the Gulf, whereas hawks and vultures have never been recorded flying over this large water body, making the shoreline of the Gulf of Mexico an effective barrier delimiting the eastern extent of this flyway.

Daily autumn counts have been collected from 20 August to 20 November of 1992-2004, and spring counts (roughly) from 20 February through 15 May of 1991, 1994, 1995, and 2004, from o8hoo-18hoo. Field teams collected hourly weather, flight-recording conditions, and migrant count totals, following the protocol of the Hawk Migration Association of North America (Kerlinger 1989, HMANA 2009). For a detailed description of the methods in use, please see Ruelas (2005), and Ruelas et al. (2005).

\section{Precision of Veracruz migration counts}

Accepting our suggested revisions also implies accepting a level of precision in Veracruz migration counts. Any person who has witnessed the autumn migration in Veracruz (e.g. the c. 500 ornithologists attending the IV North American Ornithological Conference that visited our two monitoring sites in October 2006) can easily reach the conclusion that accurate counts are impossible due to the large volume of migration (Figure 1 ).

The method of collecting this information in the field involves a team of three field biologists per site that are randomly assigned to teams and localities. Most birds occur in large flocks that use the thermal convection of the atmosphere for cross-country flights (Pennycuick 1998). These counts were made once the thermal-climbing period had finished and birds were in their

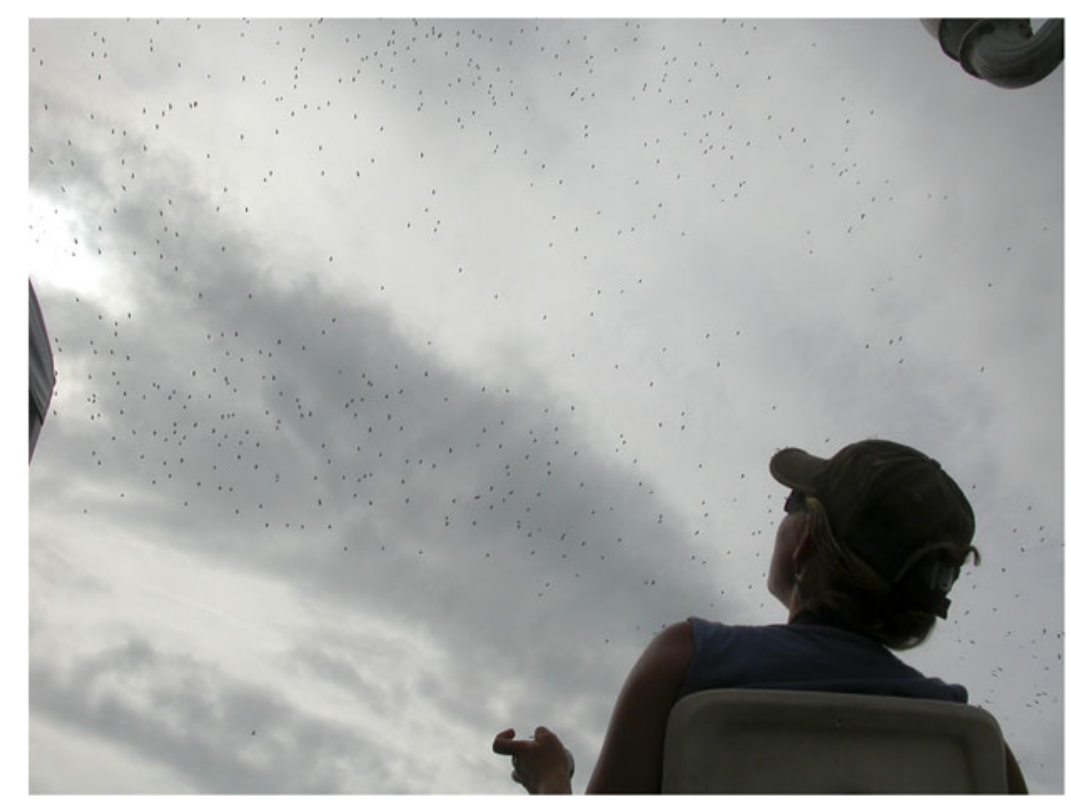

Figure 1. Field biologist Eileen Müller Guerra estimates the number of hawks in a flock past the Cardel migration monitoring site in Veracruz, México (A total of 547 within the picture frame; photo courtesy of Aldo Contreras Reyes). 
straight-line gliding flights. Our field teams directly counted the number of birds when quantities were low (e.g., a few tens) and made estimations when numbers were large. Teams estimated the number of birds with the help of a hand tally-counter by counting a small group of birds, e.g. 10 individuals, and extrapolating the approximate area occupied by these 1o birds to the rest of the flock. Most commonly-used multiples in these estimations were 3, 5, 10, and 50 individuals.

This method has been applied consistently over the years, and the relatively low interannual variation in a 13-yr series of data (Table 1), suggests that the level of error of these estimates remains relatively constant (Smith et al. 2008). Variation in migration counts is lower than the variation reported among BBS routes for most raptor species (Farmer et al. 2007). We have performed some experiments using slides, bird-counting software (Wildlife Counts http:// www.wildlifecounts.com/), and video, and concur with other sources of information (Erwin 1982, Hodges 1993) that our methods produce conservative estimates, particularly for large-flocking migrants. Although the magnitude of such underestimations has not been assessed quantitatively, calculating this underestimation would be a good avenue to pursue for future estimates. Estimations of lower quantities of birds, however, are more precise than those of higher magnitude.

We compared our mean, minimum, and maximum, annual autumn count of each species with existing North American population estimates from different published sources. Most water bird species estimates originate from colony counts and aerial surveys, while those of vultures and raptors are primarily from the BBS. Population estimates made by the authors listed under each species section have recently been revised by Kushlan et al. (2002), Rich et al. (2004), Delany and Scott (2006) and Partners in Flight (2007). It is important to notice that our migration count data includes both juvenile and adult individuals, as the two age classes are impossible to track separately in the field, while the estimates of all the remaining published sources reportedly include only reproductive individuals.

\section{Results and Discussion}

American White Pelican Pelecanus erythrorhynchos. The global estimated population of this species is variable: 106,690 individuals $(53,345$ nests $\times 2$ fide Koonz 1987); 120,000 individuals (Kushlan et al. 2002); 134,000 individuals "east of the Rocky Mountains" (King and Anderson 2005), and over 180,000 (Delany and Scott 2006: 31). The mean Veracruz count $(85,679$ individuals, Table 1 ) is lower than any of the North American estimates. However, since the majority (over $80 \%$ ) of the winter range for this species lies north of our study sites in both the Gulf and the Pacific coasts (Knopf 2004), and, since these populations do not migrate through Veracruz, it is reasonable to state that Delany and Scott's (2006) highest estimate is substantially

Table 1. Autumn migration count totals of seven species of wading birds, vultures, and hawks from Veracruz, México, 1992-2004, and previously-published North American population estimates (see text for source data). SD, standard deviation; $\mathrm{CV}$, coefficient of variation.

\begin{tabular}{|c|c|c|c|c|c|c|c|}
\hline & \multicolumn{5}{|c|}{ Season count total ( $n=13$ field seasons) } & \multirow{2}{*}{$\begin{array}{l}\text { Highest Old } \\
\text { Estimate }\end{array}$} & \multirow{2}{*}{$\begin{array}{l}\text { New } \\
\text { Estimate }\end{array}$} \\
\hline & Mean & Min & Max & SD & $\mathrm{CV}$ & & \\
\hline American White Pelican & 85,679 & 54,507 & 128,757 & 32,476 & $37 \cdot 9$ & $>_{180,000}$ & $?$ \\
\hline Anhinga & 31,633 & 18,837 & 41,440 & 9,011 & 28.4 & 51,000 & $?$ \\
\hline Wood Stork & 56,975 & 24,915 & 121,791 & 33,205 & 58.2 & 46,000 & $>60,000$ \\
\hline Turkey Vulture & $1,895,679$ & $1,474,797$ & $2,677,355$ & 387,839 & 20.4 & $1,305,000$ & $>2,086,000^{1}$ \\
\hline Mississippi Kite & 157,199 & 32,568 & 306,274 & 87,640 & $55 \cdot 7$ & 190,000 & 181,000 \\
\hline Broad-winged Hawk & $1,931,255$ & $1,534,556$ & $2,389,232$ & 287,822 & 14.9 & $1,728,000$ & $2,125,000$ \\
\hline Swainson's Hawk & 812,419 & 388,916 & $1,197,850$ & 280,788 & $34 \cdot 5$ & 460,600 & 894,000 \\
\hline
\end{tabular}

${ }^{1}$ This estimate includes populations from northeastern México 
low, possibly as much as $60 \%$, assuming a homogenous winter density, and therefore this estimate needs to be revised. An appropriate method for a more accurate estimate should include colony counts and winter density estimations across the non-breeding range of the species, possibly aided with Christmas Bird Count (CBC) data. Migration counts from localities north and south of our field sites could also help refine these estimates.

Anhinga Anhinga anhinga. Current North American population estimates range from 20,000-34,000 individuals (10,000-17,000 pairs $\times 2$ fide Frederick and Siegel-Causey 2000 and Kushlan et al. 2002) to 51,00o individuals for the south eastern United States alone (Delany and Scott 2006: 39). A very large proportion of the population of this species overwinters in its breeding range (Frederick and Siegel-Causey 2000), and therefore is not recorded during migration in Veracruz. Our mean autumn count of 31,633 (Table 1), may record less than $40 \%$ of the individuals that belong to the migrating population (this estimate is based on the range map in Frederick and Siegel-Causey 2000), and therefore indicates that all previous population estimates are low and should also be revised. We are unable to determine how low this estimate might be, but suggest that migration counts, non-breeding season colony counts, CBC, and winter density estimations paired with non-breeding season geographic distribution data, could help obtain a more precise number.

Wood Stork Mycteria americana. This species is estimated to have 25,000 individuals in the United States breeding range (Coulter et al. 1999). Delany and Scott (2006: 56) estimate 28,000 individuals for the southeastern United States alone. A more recent figure of 46,0oo individuals includes México and Central America (Kushlan et al. 2002).

The mean number recorded in Veracruz is higher than any of these figures $(56,975$, Table 1 ) and nearly $20 \%$ larger than the highest published estimate. These results suggest that previous population estimates for North America are conservative, but in the case of those including Mexico and Central America (Kushlan et al. 2002) these numbers are too conservative, up to $65 \%$ below, based on winter range distribution relative to our field sites, and therefore these should be revised.

Wood Storks recorded on southbound autumn migration in Veracruz include an unknown proportion of juveniles that migrate north along the Gulf coast from colonies in the wetlands of the Grijalva and Usumacinta rivers (Tabasco and Chiapas) and the region of Centla (Tabasco), and possibly from the states of Campeche and Yucatán, during their post-fledgling period from late May through July. These individuals may join southbound migrants of northern origin later in the autumn and the number of individuals recorded in autumn migration counts may not belong to populations originating exclusively in the southeastern United States, but include birds from southern México. An adequate knowledge of the post-breeding dispersal and migration ecology of this species, colony counts in the non-breeding season, and migration counts will also be helpful in producing more appropriate estimates.

Turkey Vulture Cathartes aura. Population estimates cover the broad and expanding range of this species throughout North America (Kirk and Mossman 1998). The United States and Canada population estimate in Rich et al. (2004) is 1,305,000 individuals (or $29 \%$ of 4,500,000 globally). Our mean annual count is higher $(1,895,679$, Table 1$)$ exceeding the highest published figure by over $30 \%$, yet, Veracruz counts detect only a portion of the North American breeding population. Much (very likely more than $50 \%$ ) of the eastern population of Turkey Vultures does not migrate as far as Mexico during the winter period (Kirk and Mossman 1998).

Our field sites are not sampling a proportion of the population migrating west of our study sites (10\%), since thermal-soaring obligates such as this species, are restricted to the lowlands of the coastal plain where they find abundant thermals for energy-saving migration. Our rounded estimate of the North American and northern México population migrating through Veracruz is 2,945,00o individuals. An accurate estimation of the North American population requires more information on the geography of migration of this species.

Mississippi Kite Ictinia mississippiensis. The North American global population estimate by Rich et al. (2004) is 190,000 individuals, very similar to the estimate of Parker (1999), who 
obtained this information from our count data. This is a total migrant (breeding and wintering ranges are disjunct), whose most important migration route is the Gulf coastal plain of México, and a very high percentage of the global population of this species is recorded in our count sites. The mean number recorded in Veracruz is 157,199 (Table 1).

The number of Mississippi Kites tracked in our field sites is a sample of the total population migrating through this area. This is a facultative thermal-soaring migrant in Veracruz, and a proportion of the flight that we estimate to be $15 \%$ (and this percentage is slightly larger than in species of thermal-soaring obligates, Ruelas 2005), is missed west (inland) of our study sites; therefore, our rounded population estimate for this species is 181 , ooo individuals. This species is undergoing an explosive population increase, at a rate of $>_{15} \%$ per year (Smith et al. 2008).

Broad-winged Hawk Buteo platypterus. Global population estimates of 1.7 million individuals are based on research from our study site (Goodrich et al. 1996). This estimation concurs with the one of Rich et al. (2004) of $1,728,000$ individuals ( $96 \%$ of $1,800,000$ ). The mean number recorded in Veracruz $(1,931,255$, Table 1$)$ is slightly larger than earlier North American estimates. This species is a total migrant and, with the exception of populations overwintering in southern Florida and individuals migrating into Cuba, a very large proportion of the global population is recorded during migration in Veracruz. The Broad-winged Hawk is a thermalsoaring obligate restricted to the coastal plain and we estimate that $10 \%$ of the transient population is not sampled west of our study sites. Our rounded estimate for North America is 2,125,000 individuals.

Swainson's Hawk Buteo swainsoni. This is another species of total migrant whose global population estimates are based on unpublished data from our research sites (Ruelas et al. 1996). During the period 1995-1996, our most conservative estimate was 448,000 (England et al. 1997), which coincides with the figure provided by Rich et al. (2004) of around 460,600 (94\% of $490,000)$. The mean number recorded in Veracruz $(1,197,850$ birds, Table 1$)$ is $56.6 \%$ larger than the previous highest population estimate.

The migration of this 'western' species follows a path across northern México into the Gulf coastal plain and most Swainson's Hawks overwinter in Argentina, with the exception of populations in California, western México (Binford 1989), and Florida (England et al. 1997). The disjunct distribution of this species in the breeding and wintering area, the limited options for migration routes, and the outcome of migration counts and satellite telemetry studies suggest a very large proportion of the global population migrates through this bottleneck (e.g. Fuller et al. 1998). Swainson's Hawk is also a thermal-soaring obligate restricted to the coastal plain and we estimate our sites are missing $10 \%$ of the total population transient through the area. Our rounded population estimate is 894, ooo individuals.

\section{Population estimates as a product of a metanalysis}

The main difference between the Global Waterbird (Delany and Scott 2006), European (Burfield and van Bommel 2004), and North American (Rich et al. 2004) population assessments is that the first two use an approach that combines data from multiple types of surveys that cover the breeding and the non-breeding season, whereas the latter is based almost completely upon BBS data that most likely excludes all non-breeding adult and juvenile individuals (Rich et al. 2004: 79, Rosenberg and Blancher 2005).

The authors of the North American landbird estimates (Rich et al. 2004, Blancher et al. 2007) acknowledge the limitations of this single-survey-based approach. Including data from different surveys could enable us to derive more appropriate population estimates, since no survey is capable of generating abundance indices for all species.

This is particularly important in the case of raptors. BBS data have been shown to have limitations estimating trends and indices of abundance in species detected at rates of $<$ 1.o birds per route (Peterjohn et al. 1995), which is the case for all the species treated in this paper. 
Similarly, Farmer et al. (2007) have shown that, for most species, BBS population change estimates are of lower precision than those of migration counts.

\section{Towards a precise conservation tool}

The word of caution offered by Rosenberg and Blancher (2005: 65), that "using inaccurate population estimates to set conservation targets may lead to misdirected conservation actions" is of critical importance. One example of this is the recently recovered Peregrine Falcon (Falco peregrinus). The estimate of Rich et al. (2004) for the North America population is 276,000 ( $23 \%$ of $1,200,000$ worldwide). However, an estimate based on nest surveys by White et al. (2002), suggests the North American population ranges between 52,000 and 62,000 individuals, less than one-quarter than reported in the PIF estimate. As we further monitor the recovery of this species and the impact of management activities on their regional populations (Millsap and Allen 2006, USFWS 2007), it becomes essential to work with the best population estimates possible.

The opportunity to have a revised database of population estimates as a conservation tool of high precision may be in front of us. The PIF population estimates are now available at the state level (Partners in Flight 2007). The PIF Science Committee use the BBS-based approach (Blancher et al. 2007) that will soon incorporate the suggestions of Thogmartin et al. (2006) at this level of detail (P. Blancher, pers. comm.). Now that these state-level, baseline data exist, the fine-grain resolution will facilitate reducing the error of these estimates and will be open to the contribution of more data from other surveys and researchers (Confer et al. 2008, Lanctot et al. 2008). An adjustment to these estimates, like the one in our case study using migration count data at a large scale, is more feasible at finer scales.

Generating these first baseline data should be considered a work in progress, rather than a final word, in the creation of this collaborative conservation tool (Lanctot et al. 2008, Farmer 2008). We believe that (I) The contribution of data derived from diverse surveys, and (2) Sampling data from individual projects that involve large proportions of the population of interest, enhances the precision and value of North American estimates.

\section{Acknowledgements}

We thank Peter Blancher, Tony Diamond, and Stuart Marsden for reviewing this paper and for their suggestions for improvement. Wesley Hochachka, Stefan Hames, André Dhondt's Lab group (Bird Population Studies, Cornell Lab of Ornithology), Peter Vickery, and John Faaborg also provided criticism of this manuscript. We thank long-term sponsors of the Veracruz River of Raptors Project, National Fish and Wildlife Foundation, U.S. Fish and Wildlife Service's Neotropical Migratory Bird Conservation Act, Lannan Foundation, American Bird Conservancy, Fondo Mexicano para la Conservación de la Naturaleza, John D. and Catherine T. MacArthur Foundation, Lincoln Park Zoo, U.S. Agency for International Development mission in Mexico City, Hawk Mountain Sanctuary, HawkWatch International, Pronatura Veracruz, and many private donors. We extend our gratitude to our dedicated field crews. ERI is indebted to John Faaborg and the University of Missouri for their support for this project; this paper was written while supported by a Howard Hughes Medical Institute postdoctoral fellowship through Dartmouth College. This is Hawk Mountain Sanctuary contribution to conservation science No. 182.

\section{References}

Bibby, C. J., Burgess, N. D., Hill, D. A. and Mustoe, S. H. (2000) Bird census techniques. London: Academic Press.
Binford, L. C. (1989) A distributional survey to the birds of the Mexican state of Oaxaca. Lawrence, Kansas: American 
Ornithologists' Union. Ornithological Monographs No. 43.

Blancher, P. J., Rosenberg, K. V., Panjabi, A. O., Altman, B., Bart, J., Beardmore, C. J., Butcher, G. S., Demarest, D., Dettmers, R., Dunn, E. H., Easton, W., Hunter, W. C., Iñigo-Elías, E. E., Pashley, D. N., Ralph, C. J., Rich, T. D., Rustay, C. M., Ruth, J. M. and Will, T. C. (2007) Guide to the Partners in Flight population estimates database. Version: North American landbird conservation plan 2004. Partners in Flight Technical Series No. 5. http://www.partnersinflight. org/

Burfield, I. and van Bommel, F. (2004) Birds in Europe: population estimates, trends and conservation status. Cambridge, UK: BirdLife International. BirdLife Conservation Series No. 12.

Confer, J. L., Serrell, R. E., Hager, M. and Lahr, E. (2008) Field tests of the RosenbergBlancher method for converting point counts to abundance estimates. Auk 125: 932-938.

Coulter, M. C., Rodgers, J. A., Ogden, J. C. and Depkin, F. C. (1999) Wood Stork (Mycteria americana). The Birds of North America 409. Philadelphia, USA: The Birds of North America, Inc.

Delany, S. and Scott, D. (2006) Waterbird population estimates. Fourth Edition. Wageningen, The Netherlands: Wetlands International.

England, A. S., Bechard, M. J. and Houston, C. S. (1997) Swainson's Hawk (Buteo swainsoni). The Birds of North America 265. Philadelphia, USA: The Academy of Natural Sciences and The American Ornithologists' Union.

Erwin, R. M. (1982) Observer variability in estimating numbers: an experiment. J. Field Ornith. 53: 159-167.

Faaborg, J. (2005) Partners in Flight North American landbird conservation plan (book review). Auk 122: 373-375.

Farmer, A. H. (2008) "Anchoring" and research priorities: factors that depress bird population estimates? Auk 125: 980-983.

Farmer, C. J., Hussell, D. J. T. and Mizrahi, D. (2007) Detecting population trends of migratory birds of prey. Auk 124: 10471062.
Flather, C. H. and Sauer, J. R. (1996) Using landscape ecology to test hypotheses about large-scale abundance patterns of migratory birds. Ecology 77: 28-35.

Fitzpatrick, J. W. (2002) The AOU and bird conservation: recommitment to the revolution. Auk 119: 907-913.

Frederick, P. C. and Siegel-Causey, D. (200o) Anhinga (Anhinga anhinga). The Birds of North America 522. Philadelphia, USA: The Birds of North America, Inc.

Fuller, M. R., Seegar, W. S., and Schueck, L. S. (1998) Routes and travel rates of migrating Peregrine Falcons Falco peregrinus and Swainson's Hawks Buteo swainsoni in the western hemisphere. J. Avian Biol. 29: 433440.

Goodrich, L. J., Crocoll, S. C. and Senner, S. E. (1996) Broad-winged Hawk (Buteo platypterus). The Birds of North America 218. Washington, D.C. and Philadelphia, USA: The Academy of Natural Sciences and The American Ornithologists' Union.

HMANA. (2009) A standard data-collection protocol for raptor migration monitoring. Hawk Migration Association of North America http://www.hmana.org/

Hodges, J. I. (1993) Count - a simulation for learning to estimate wildlife numbers. Wildl. Soc. Bull. 21: 96-97.

Kerlinger, P. (1989) Flight strategies of migrating hawks. Chicago and London: University of Chicago Press.

King, D. T. and Anderson, D. W. (2005) Recent population status of the American White Pelican: a continental perspective. Waterbirds 28 (Special Publication 1): 4854 .

Kirk, D. A. and Mossman, M. J. (1998) Turkey Vulture (Cathartes aura). The Birds of North America 339. Philadelphia, USA: The Birds of North America, Inc.

Koonz, W. H. (1987) Status update, the American White Pelican Pelecanus erythrorhynchos in Canada. Ottawa, Canada: Committee on the Status of Endangered Wildlife in Canada, Canadian Wildlife Service.

Knopf, F. L. (2004) American White Pelican (Pelecanus erythrorhynchos). The Birds of North America Online. Ithaca, New York: Cornell Laboratory of Ornithology http:// 
bna.birds.cornell.edu/BNA/account/

American_White_Pelican/

Kushlan, J. A., Steinkamp, M. J., Parsons, K. C., Capp, J., Acosta, C. M., Coulter, M., Davidson, I., Dickson, L., Edelson, N., Elliot, R., Erwin, R. M., Hatch, S., Kress, S., Milko, R., Miller, S., Mills, K., Paul, R., Phillips, R., Saliva, J. E., Snydeman, B., Trapp, J., Wheeler, J. and Wohl, K. (2002) Waterbird conservation for the Americas: The North American waterbird conservation plan, Version 1. Washington, DC: Waterbird Conservation for the Americas. Lanctot, R. B., Hartman, A., Oring, L. W. and Morrison, G. (2008) Response to Farmer (2008): limitations of statistically derived population estimates, and suggestions for deriving national population estimates for shorebirds. Auk 125: 983-985.

Millsap, B. A. and Allen, G. T. (2006) Effects of falconry harvest on wild raptor populations in the United States: theoretical considerations and management recommendations. Wildl. Soc. Bull. 34: 1392-1400.

Parker, J. W. (1999) Mississippi Kite (Ictinia mississippiensis). The Birds of North America 402. Philadelphia, USA: The Birds of North America, Inc.

Partners in Flight. (2007) PIF Landbird Population Estimates Database. Partners in Flight http://rmbo.org/pif_db/laped/

Pennycuick, C. J. (1998) Field observations of thermals and thermal streets, and the theory of cross-country soaring flight. J. Avian Biol. 29: 33-43.

Peterjohn, B. G., Sauer, J. R. and Robbins, C. S. (1995) Population trends from the North American Breeding Birds Survey. Pp. 3-39 in T. E. Martin and D. M. Finch, eds. Ecology and management of Neotropical migratory birds: a synthesis and review of critical issues. London: Oxford University Press.

Ralph, C. J. and Scott, M. (1981) Estimating numbers of terrestrial birds. Lawrence, Kansas: Cooper Ornithological Society. Studies in Avian Biology No. 6.

Rich, T. D., Beardmore, C. J., Berlanga, H., Blancher, P. J., Bradstreet, M. S. W., Butcher, G. S., Demarest, D. W., Dunn, E. H., Hunter, W. C., Iñigo-Elías, E. E., Kennedy, J. A., Martell, A. M., Panjabi, A. O., Pashley, D. N., Rosenberg, K. V., Rustay, C. M., Wendt,
J. S. and Will, T. C. (2004) Partners in Flight North American landbird conservation plan. Ithaca, New York: Cornell Laboratory of Ornithology.

Rosenberg, K. V. and Blancher, P. J. (2005) Setting numerical objectives for priority landbird Species. Pp. 57-67 in C. J. Ralph and T. D. Rich, eds. Bird conservation implementation and integration in the Americas: proceedings of the third international Partners in Flight conference, Volume 1. Albany, CA: Pacific Southwest Research Station, Forest Service, U.S. Department of Agriculture. General Technical Report PSW-GTR-191.

Ruelas, I. E. (2005) Raptor and wading bird migration in Veracruz, Mexico: spatial and temporal dynamics, flight performance, and monitoring applications. Ph.D. Dissertation. University of Missouri. Columbia, Missouri, United States.

Ruelas, I. E., Goodrich, L. J., and Hoffman, S. W. (1996) Dynamics of fall raptor migration through Veracruz, Mexico: monitoring and conservation implications (Paper presentation). Boise, Idaho: American Ornithologists' Union - Raptor Research Foundation Joint Meeting.

Ruelas, I. E., Goodrich, L. J., Hoffman, S. W. and Tingay, R. (2000) Conservation strategies for the world's largest raptor migration flyway: Veracruz, the River of Raptors. Pp. 591-596 in R. D. Chancellor and B.-U. Meyburg, eds. Raptors at risk. Durban, South Africa: World Working Group on Birds of Prey.

Ruelas, I. E., Hoffman, S. W. and Goodrich, L. J. (2005) Stopover ecology of Neotropical migrants in Veracruz, Mexico. Pp. 657-673 in C. J. Ralph and T. D. Rich, eds. Bird conservation implementation and integration in the Americas: proceedings of the third international Partners in Flight conference, Volume 2. Albany, CA: Pacific Southwest Research Station, Forest Service, U.S. Department of Agriculture. General Technical Report PSW-GTR-191.

Smith, J. P., Farmer, C. J., Hoffman, S. W., Lott, C. A., Goodrich, L. J., Simon, J., Riley, C. and Ruelas, I. E. (2008) Trends in autumn counts of migratory raptors around the Gulf of Mexico, 1995-2005. Pp. 253-278 in K. L. 
Bildstein, J. P. Smith, E. Ruelas I. and R. R. Veit, eds. The state of North America's birds of prey. Cambridge, Mass: American Ornithologists'Union and Nuttall Ornithological Club Series in Ornithology No. 3.

Thogmartin, W. E., Howe, F. P. James, F. C., Johnson, D. H., Reed, E. T., Sauer, J. R. and Thompson, F. R. III. (2006) A review of the population estimation approach of the North American bird conservation plan. Auk 123: 892-904.

Tucker, G. M., Heath, M. F., Tomialojc, L. and Grimmett, R. F. A. (1994) Birds in Europe: their conservation status. Cambridge, UK: BirdLife International. BirdLife Conservation Series 3 .
USFWS. (2007) U.S. Fish and Wildlife Service seeks comment on proposal to allow falconers to remove and possess migratory Peregrine Falcons from the wild. U. S. Fish and Wildlife Service http://www.fws.gov/news/newsreleases $/$ showNews.cfm?newsId = $3 \mathrm{~A}_{9} \mathrm{ADB}_{1} \mathrm{C}-$ B5A7-oD79-07E6459C83CD0595

Vickery, P. D. and Shriver, W. G. (2005) The road map to North American bird conservation (book review). Conserv. Biol.19: 2044-2046.

White, C. M., Clum, N. J., Cade, T. J. and Hunt, W. G. (2002) Peregrine Falcon (Falco peregrinus). The Birds of North America 66o. Philadelphia, USA: The Birds of North America, Inc.

\section{ERNESTO RUELAS INZUNZA*}

Pronatura Veracruz, Apartado Postal 399, Xalapa, Veracruz, México 91000.

Current address: Dartmouth College, Biology Department, Gilman Hall, Hanover, NH 03755 , U.S.A.

\section{LAURIE J. GOODRICH}

Acopian Center for Conservation Learning, Hawk Mountain Sanctuary, 410 Summer Valley Rd., Orwigsburg, PA 17961, U.S.A.

\section{STEPHEN W. HOFFMAN}

HawkWatch International, 2240 S. 900 E., Salt Lake City, UT, United States 84106.

Current address: Montana Audubon, P. O. Box 595, Helena, MT 59624, U.S.A.

${ }^{*}$ Author for correspondence; e-mail: ernesto.ruelas@dartmouth.edu 